American Journal of Agricultural and Biological Sciences 2 (2): 49-53, 2007

ISSN 1557-4989

(C) 2007 Science Publications

\title{
Genetic Variation and Relationship Between Turkish Flint Maize Landraces by RAPD Markers
}

\author{
A. Okumus \\ Agriculture Faculty, Department of Animal SciencelBiometry-Genetics Unit, Ondokuz Mayis \\ University, 55139, Samsun, Turkey
}

\begin{abstract}
A comparative characterization of 17 flint maize landraces (Zea mays L.) was carried out using RAPD markers. Fourteen primers giving reliable and consistent polymorphic bands amplified 125 fragments $(89 \%)$ with an average of 8.90 fragment per primer. Genetic variation in 17 maize landraces was characterized based on dissimilarity matrix by UPGMA dendogram which has no association into distinct grouping with respect to locations and many small clusters formed. The similarity was in range from 0.05 to 0.88 . It is interesting that there was close relationship among yellow and yellow-orange endosperm accessions with the dissimilarity between 0.08 and 0.20 . The group containing mostly white endosperm accessions displayed a range of genetic distance. It is considered that isolated accessions showed the highest genetic distance has a uncertain origin derived from a sample collected by landholder farmer. Turkish flint accessions had a high variability crossing from the different maize genetic resources. Only, isolated small landholder farmers kept the landraces without pollination from the different source of germplasm. These results will be able to help to maintain a germplasm collection with the genetic diversity among maize landraces for breeding program of maize in Turkey.
\end{abstract}

Key words: Turkish flint landrace, maize, RAPD, color

\section{INTRODUCTION}

The genetic information of a landrace can allow the possible explanation of genes for traits such as disease resistance, tolerance to environmental stresses by conservation of landraces which have high genetic variability with the fitness to the environments where they have originated ${ }^{[1]}$. Genetic knowledge of germplasm diversity among local populations has a significant impact on the improvement of plants not only a valuable source of useful traits but also a bank of highly adapted genotypes ${ }^{[2,3,]}$. The genetic diversity has been assessed more efficiently relating polymorphism from the morphological, biochemical and DNA labels. Genetic variability in landraces has been studied by morphological traits ${ }^{[4,5,6,7,8]}$ and isozyme ${ }^{[9,10,11,12,13,14]}$. DNA polymorphism assays are powerful tools for characterizing and studying germplasm resources ${ }^{[15]}$. The first molecular markers used in maize breeding programme are RFLP $\left.{ }^{[16,} 17\right]$. Markers based on polymerase chain reaction have been used in analysis of genetic distance such as RAPD ${ }^{[4]}$. RAPD markers are commonly used enabling genetic diversity analysis for plant populations in breeding program and germplasm collections ${ }^{[19]}$. RAPD markers were better where easy applications and cost were considered comparing RFLP $[20,21]$. In maize, RAPD markers have been used in describing genetic diversity between maize accessions $^{[7,22]}$.

Maize is the most extensively cultivated crop in

Turkey after wheat ${ }^{[23]}$. The introduction of maize (Zea mays L.) to Turkish cultivation system goes back around 1600 A.D. thought Ottoman traders following Spanish explorers to the Mediterranean coasts ${ }^{[12,24]}$. Up to date, newer landraces have originated from introduced populations with adaptation to local conditions. On the other hand, planned introduction of maize accessions to Turkey were made by Agricultural Institutions in Turkey until 1950s ${ }^{[24]}$. Farmers used open-pollinated varieties of maize with traditional farming practices until last quarter of this century when hybrids were introduced to Turkey.

Black Sea Region of Turkey is one of the areas that maize growths. The structure of regions with rainy climate and narrow growing area allows growing the maize at the coastal sides. Maize is growth in this area for long time, traditionally. The seeds are produced from the former plant's seeds with limited seed exchange with other farmers. Most of the people use 
maize for human and animal consumption and they do not use hybrids except plain areas with the low altitude. So, the region conserves the maize resources with traditional practices. The genetic diversity between flint Turkish maize landraces growing at the north of Turkey is not known although it shows different color of kernel types. The purpose of the present study is to assess genetic diversity among populations of these landraces in 17 cultivated accessions of landraces by molecular markers.

\section{MATERIAL AND METHODS}

Plant material: Seeds of seventeen maize accessions were obtained from north of Turkey which shoed the characteristics of flint maize group. The accessions were selected to represent the whole north of Turkey in different altitudes and maintained in reproductive isolation by traditional agricultural farming for years of farmer-directed selection. Each accessions were represented by 20 individuals and kernels randomly sampled in four different ears on the basis of morphology. Polymorphism degree and genetic relationships among 17 maize landraces were evaluated with RAPD markers. The collection of flint maize accessions included different kernel color which can be used in the germplasm evaluation with flowering time according to Nass and Paterniani ${ }^{[25]}$. Flowering time changes due to the environmental conditions and it occurs between 40 and 100 days, generally ${ }^{[26]}$. The accessions were also evaluated in the flowering time (Table 1).

Table 1: The genotype code, locality, kernel color of Turkish flint maize accessions.

\begin{tabular}{lcllr}
\hline No. & $\begin{array}{c}\text { Genotype } \\
\text { code }\end{array}$ & Locality & Kernel color & \multicolumn{2}{c}{$\begin{array}{l}\text { Altitude } \\
(\mathbf{m})\end{array}$} \\
\hline 1 & 12 & Çatalarmut & Yellow & 120 \\
2 & 16 & Keresteci1 & Yellow & 10 \\
3 & 19 & Eğercili1 & White & 10 \\
4 & 20 & Eğercili2 & Yellow & 10 \\
5 & 21 & Rize-Pazar & Yellow & 350 \\
6 & 25 & Trabzon -Tonya & Yellow & 1000 \\
7 & 27 & Tokat-Niksar1 & Yellow & 530 \\
8 & 28 & Tokat-Niksar2 & White & 530 \\
9 & 31 & Çorum & Yellow & 550 \\
10 & 43 & Artvin & White & 900 \\
11 & 46 & Ordu-Kumru & Yellow-orange & 500 \\
12 & 49 & Keresteci2 & Yellow-orange & 10 \\
13 & 51 & Elifli & White & 20 \\
14 & 57 & Terme & White & 20 \\
15 & 67 & Eğercili 6(3) & Yellow & 10 \\
16 & 68 & Ordu-İkizce & Yellow & 600 \\
17 & 86 & Asarcik & White & 600 \\
\hline
\end{tabular}

DNA extraction and amplification: Maize leaves were collected from the healthy seedlings and frozen in liquid nitrogen. Genomic DNA was isolated from the leaf samples according to the protocol of CTAB described by Doyle\&Doyle ${ }^{[27]}$. DNA samples were measured in a fluorometer (EppendorfSpectrofotometer) adjusting to $5 \mathrm{ng} / \mu \mathrm{l}$. PCR reactions for RAPD were done in a volume of $25 \mu$ l containing $13 \mu 1$ master mix (Promega), $25 \mathrm{ng}$ DNA template, 20 ng of 10-mer primer (Operon Technology) and deionize water. The PCR mix was settled to Hybaid thermal cycles with the following program: initial denaturation step for 2 min following 40 cycles at $94{ }^{\circ} \mathrm{C}$ for $1 \mathrm{~min}$, $38^{\circ} \mathrm{C}$ for 2 min and $72{ }^{\circ} \mathrm{C}$ for $2 \mathrm{~min}$ and a final cycle at $72{ }^{\circ} \mathrm{C}$ for $10 \mathrm{~min}$. The amplified products were separated by agarose electrophoresis in $1.5 \%$ (SIGMAlow melting agarose) in $0.5 \times$ TAE buffer (Tris Base 0.04 $\mathrm{M}$ and EDTA $0.01 \mathrm{M} \mathrm{pH} 8.3$ ), containing $0.10 \mu \mathrm{g} / \mu \mathrm{l}$ of ethidium bromide. The gels were runned under $100 \mathrm{~V}$ for $5 \mathrm{~h}$ and transferred to gel documentation system (Syngene) for analysis. Molecular sizes of the products were estimated by Lambda DNA (wide range markerSIGMA).

Data analysis: PCR products of eleven polymorphic primers to represent a single locus and data were scored for presence (1) and absence ( 0 ) of the respective bands in each population. Genetic distance (GD) values were calculated between all pairs of accessions according to Jaccard's Formula ${ }^{[28]}$. The dissimilarity matrix was used to assess the relationships among landrace populations with a dendogram constructed by cluster analysis using UPMGA using NTSYS computer program, Version $2.11^{[29]}$.

\section{RESULTS AND DISCUSSION}

RAPD marker analysis: Totally, 160 primers were screened and 14 of them were found to be valuable for RAPD analysis. One hundred and fourtysix primers (91\%) yielded either monomorphic or unreproduciple fragments. The remaining 14 primers giving reliable and consistent polymorphic bands were used to amplify genomic DNA of the 17 maize accessions (Table 2). To increase analysis precision, weak bands occurring from low homology between the primer and the pairing site were disregarded ${ }^{[21,30]}$. A total 125 fragments, in range of 180 (OPC-11) to 1500 (OPC-9) bp were analysed with an average of 8.90 fragment per primer. 
Table 2: The primer sequence, number of total band, shared bands and size of fragments of used decamers

\begin{tabular}{lcc}
\hline Primer & Sequence & Size of Fragments \\
\hline OPC-1 & TTCGAGCCAG & $390-960$ \\
OPC-02 & GTGAGGCGTC & $280-1050$ \\
OPC-07 & GTCCCGACGA & $550-1500$ \\
OPC-08 & TGGACCGGTG & $350-1100$ \\
OPC-09 & CTCACCGTCC & $330-1200$ \\
OPC-15 & GACGGATCAG & $180-980$ \\
OPC-19 & GTTGCCAGCC & $300-1050$ \\
OPD-03 & GTCGCCGTCA & $300-1500$ \\
OPD-05 & TGAGCGGACA & $300-1300$ \\
OPD-08 & GTGTGCCCCA & $330-830$ \\
OPD-18 & GAGAGCCAAC & $360-1260$ \\
OPD-20 & ACCCGGTCAC & $260-1200$ \\
OPE-07 & AGATGCAGCC & $340-1400$ \\
OPE-15 & ACGCACAACC & $200-1100$ \\
\hline Total/range & & $180-1500$ \\
\hline
\end{tabular}

The percentage of polymorphism was calculated as $89 \%$. It is good value of efficiency for genetic analysis that in the study done on Ethiopian highland maize accessions by Beyene et al., (2005) showed a all SSR loci and $89,5 \%$ of AFLP bands were polymorphic. This value was found lower in southern Brazilian maize accessions $^{[30]}$, in the genetic analysis of endogamic maize lines ${ }^{[31]}$, in the study of maize hybrids ${ }^{[32]}$ and in the genetic analysis among varieties on native American maize ${ }^{[22]}$.

Genetic variation and relationships among maize landraces: It is considered that Turkish maize accessions indicate large amount of genetic diversity in the most of the accessions analyzed by isozyme analysis of different maize races ${ }^{[12]}$, discriminant analysis of different races of morphologic parameters ${ }^{[8]}$ and Turkish maize accessions belonging to the north of Turkey (unpublished data).

The extent of genetic variation in 17 maize landraces was characterized based on dissimilarity matrix by UPGMA dendogram which has no association into distinct grouping with respect to locations, many small clusters formed (Figure 1). The accessions of Tokat-Niksar2, Terme, Eğercili2 and Rize-Pazar did not join to clustering with the largest genetic distance value. Ilarslan et al., ${ }^{[12]}$ reported that the most of flint maize accessions took place in the large cluster groups analyzed by isozymes without grouping with respect to locations in Turkey. Genetic distance between studied Turkish flint maize accessions revealed that accessions Tokat-Niksar2, Terme, Eğercili2 and Rize-Pazar had the highest genetic dissimilarity due to other accessions. The dissimilarity ranged between 0.116 (Ordu-İkizce x Trabzon-Tonya) to 0.947 (Terme $\mathrm{x}$ Elifli).

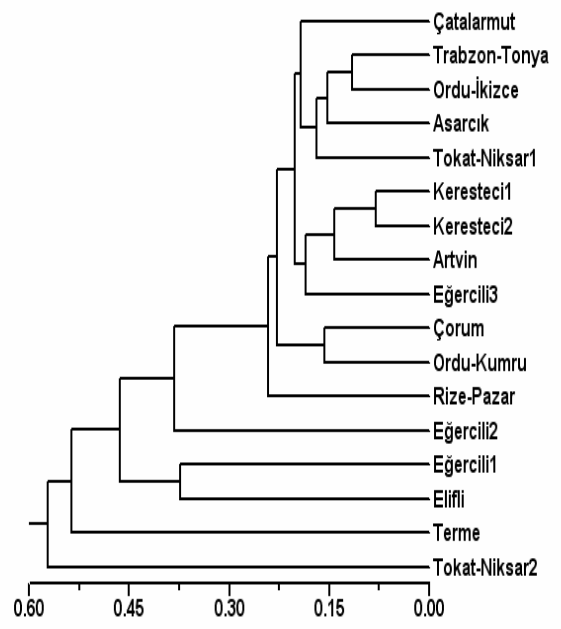

Fig. 1:Dendogram of 17 Turkish flint maize landraces constructed using UPGMA method based on a dissimilarity matrix by NTYSYs 2.1 software

It is interesting that there was close relationships among yellow and yellow-orange endosperm accessions with the dissimilarity between 0.08 and 0.20 . The group containing mostly white endosperm accessions displayed a range of genetic distance. However, Tokat-Niksar2, Terme, Eğercili1 and Elifli accessions remained isolated in the dendogram with white endosperm. It is considered that isolated accessions (Tokat-Niksar2, Terme, Eğercili1 and Elifli) showed the highest genetic distance has a uncertain origin derived from a sample collected by landholder farmer. The similar results was showed in a study done by Carvalho et al., ${ }^{[30]}$ in the Brazilian accessions on the endosperm color grouping by RAPD and in the same maize collections by inter simple sequence repeats (ISSR $^{[31]}$.

Moeller and Schall ${ }^{[22]}$ discussed the similarity index changing from 0.44 to 0.80 in Native American maize collections of Great Plains by RAPD markers. It was suggested that the high level of variability is an indicator of migration of maize accessions to other locaties. In Brazilian accessions had a similarity varied between 0.78 to $0.91^{[30]}$. The similarity in Turkish flint accessions was in range from 0.05 to 0.88 with high variability. Possibly, it represents a large fraction of the Turkish flint maize collection and Samsun territory is an origin of these accessions due to multivariate discriminant analysis (unpublished data).

The association between morphological and dendogram prepared by RAPD among open pollinated varieties have been reported by ${ }^{[30,33,34,35]}$. The low genetic distance was seen between the yellow and 
yellow-orange maize accessions studied in Kerestecil $\mathrm{x}$ Keresteci2 and Çorum x Ordu-Kumru. Whereas Trabzon-Tonya x Ordu-İkizce accessions had low genetic distance for yellow endosperm color and Elifli $\mathrm{x}$ Eğercili1 had for white endosperm.

To avoid from the replication of genetic material in the evaluation of accessions, molecular markers are important tools. The highest genetic similarity $(0.88)$ was observed between the Keresteci1 and Keresteci2 landraces. These accessions possibly have been cultivated in either distinct regions or as a result of seed exchange between unrelated farmers with the same name which the landrace was collected. Similar results reported by ${ }^{[36]}$ in the study done by isozymes analysis in 15 maize populations derived from three indigenous maize accessions. Carvalho et al., ${ }^{[30]}$ also observed similar results from the study on the 81 maize accessions in Brazilian accession by RAPD markers. The authors reported that there was no connection between the accession name and genetic relationships.

Each cluster formed several small groups and revealed the genetic divergence within the yellow color and within the white color landraces. This implies that the Turkish flint maize landraces were crossed from the different maize genetic resources in the past in different times. This can be the affect of hybrids or introductions from United States. In Black Sea Agricultural Research Institute-Samsun in Turkey, it is known that there were some practices with the accessions coming to Turkey from United States after 1960s. The results were compared to Brazilian landraces that these landraces also was derived from crossing introductions from United States in the past and maize accessions cultivated for an extended period of time ${ }^{[30,37\}}$.

\section{CONCLUSION}

In the region, the white germplasms are produced for human consumption and the yellow germplasms are growth for human and animal consumption. Some farmers prefer the white color of maize for production, only in the region. On the other hand, it was seen in some ears that there was a mix of white and yellow color of seeds and it means that there is also a seed mixture by pollen mobility. Only, isolated small landholder farmers keep the landraces without pollination from the different source of germplasm. The farmers prefer landraces because of less expensive than the commercial hybrids. Therefore, improvement of landraces is important for traditional agriculture maintenance. This will help the conservation and management of this valuable Turkish flint maize germplasm for breeding program of maize.

\section{ACKNOWLEDGEMENTS}

The Author thanks to Mr. Serhat Korkusuz for his technical assistance and Ondokuz Mayis University, Agriculture Faculty for field and lab facilities.

\section{REFERENCES}

1. Zeven, A.C. 1996. Results of activities to maintain landraces and other material in some European countries in situ before 1945 and what we learn from them. Genet. Res. and Crop. Evol. 43: 337-341.

2. Brush, S.B. 1999. The isssues of in situ conservation of crop genetic resources. In:Brush S.B. (ed.) Genes in the field. On-farm conservation of crop diversity. Lewis Publishers, Boca Raton, FL, USA Copublished by Intl. Plant Genetic Resources Institute, Rome, Italy; Intl. Development Research Centre, Ottowa, Canada, p.3-26

3. Barcaccia, G., Lucchin, M. and P. Parrini. 2003. Characterization of a flint maize (Zea mays var. indurata) Italian landrace, II. Genetic diversity and relatedness assessed by SSR and Inter-SSR molecular markers. Genetic Resources and Crop Evolution. 50: 253-271

4. 4. Bosch, L., Casanas, F., Sanchez, E. and Nuez, F. 1997. Variability of maize landraces from Northwest Spain. Plant Genetic Resources Newslet. 112:90-92

5. Azar, C., Mather, D.E. and Hamilton, R.I. 1997. Maize landraces of the St. Lawrence Great Lakes region of North America. Euphytica 98: 41-48

6. Louette, D. and Smale, M. 2000. Farmer's seed selection practices and traditional maize varieties in Cuzalapa, Mexico, Euphytica 113: 25-41

7. Beyene, Y., Botha, A. And Alexander, A.M. 2005. A comparative study of molecular and morphological methods of describing genetic relationships in traditional Ethiopian highland maize. African Jour. of Biotechbology. 4: 586-595

8. Ilarslan, R., Kaya, Z., Kandemir, I and Bretting, P.K. 2002. Genetic variability among Turkish pop, flint and dent maize(Zea mays L. spp. mays) varieties: Enzyme polymorphism. Euphytica 122: 171-179

9. Goodman, M.M. and Stuber, C.W. 1983. Races of maize. VI. Isozyme variation among races of maize in Bolivia. Maydica 28: 169-187

10. Revilla, P., Soengas, P., Malvar, R.A., Cartea, M.E. and Ordas, A. 1998. Isozyme variation and historical relationships among the maize races of Spain. Maydica 43:175-182

11. Sanau, J., Gouesnard, B. and Charrier, A. 1997. Isozyme variability in west African maize cultivars (Zea mays L) Maydica 42: 1-11

12. Ilarslan, R., Kaya, Z., Kandemir, I and Bretting, P.K. 2002. Genetic variability among Turkish pop, flint and dent maize (Zea mays L. spp. mays) varieties: Morphological and agronomical traits. Euphytica 128: 173-182 
13. Doebley, J.F. Wendel, J.D. Smith, J.S.C. Stuber, C.W. and Goodman, M.M. 1988. The origin of Cornbelt maize: The isozyme evidence. Economy Botany 42:120-131

14. Stuber, C.W., Wendel, J.F., Goodman, M.M. and Smith, J.S.C. 1988. Techniques ans scoring procedures for starch gel electrophoresis of enzymes from maize (Zea mays L.). North Carolina Agric. Res. Serv. Raleigh, N.C. USA

15. Powell, W., Morgante, M., ANdre C., Hanafey, M., Vogel, J., and Tingey S. and Rafalski, A. 1996. The comparison of RFLP, RAPD, AFLP and SSR (microsatellite) markers for germplasm analysis. Mol. Breed. 2: 225-238

16. Lee, M., Goldhalk, F.B., Lamkey, K.R. and Wodmar, W.W. 1989. Association of restriction fragment length polymorhism among maize inbreds with agronomic performance of their crosses. Crop Science, 29:1067-1071

17. Bernardo, R. 1994. Prediction of single-cross performance using RFLPs and information from related hybrids. Crop Science 34:20-25

18. Williams, J.G.K, Kubelik, A.R, Livak, K.J., Rafalski, J.A. and Tingey, S.V. 1990 DNA polymorphism amplified by arbitrary primers are useful as genetic markers. Nucleic Acids Research 18:6531-6535

19. Ferreira ME and Grattapaglia D (1996) Introdução ao uso de marcadores moleculares em análise genética. 2nd ed. EMBRAPA-CENARGEN, Brasília, pp 121-130

20. Dos Santos JB, Nienhuis J, Skroch P, Tivang J and Slocum MK (1994) Comparison of RAPD and RFLP genetic markers in determining genetic similarity among Brassica oleracea L. genotypes. Theoretical and Applied Genetic 87:909-915

21. Thormann, C.E. Ferreira, M.E. Camargo, L.E.A., Tivang, J.G. and Osborn, T.C. 1994. Comparison of RFLP and RAPD markers for estimating genetic relationships within and among cruciferous species. Theor. Appl. Genet. 88:973-980

22. Moeller D.A., Schaal, B.A. 1999. Genetics relationships among native American maize accessions of the Great Plains assessed by RAPDs. Theoretical and Applied Genetic 99:1061-106728

23. Anonymous, 2005. FAO, Faostat, www.fao.org

24. Kün, E. 1985 Warm climate cereals. Sicak iklim tahılları. Ankara University. Ziraat Fak. Pub. 953; Ders Kitabı: 275. TR

25. Nass, L.L. and Paterniani, E. 2000. Perpectivas do premelhoramento do milho. In: Udry C.W. and Duarte, W. (eds) Uma Historia Brasileira di Milho: O Valor dos Recursos Geneticos. Paralelo 15, Brasilia, 43-63

26. Goodman, M.M. and Smith, J.S.C. 1987. Botanica. In: Paterniani E. and Viegas, G.P. (orgs) Melhoramento a Produçao do Milho. Fundaçao Cargill, Campinas, 41-78.
27. Doyle, J.J., Doyle, JL. 1987 Isolation of plant DNA from fresh tissue. Focus 12: 13-15

28. Jaccard, P. 1908. Nouvelles recherchers sur la distribution florale. Bull. Vaud. Soc. Nat. 44 : 233-270

29. Rohlf F J 2000. NTSYS-pc Numerical taxonomy and multivariate analysis system, Version 2.1 (New York: Exeter)Owners manuel

30. Carvalho, V.P., Ruas, C.F., Ferreira, J.M., Moreira, R.M.P., Ruas, P.M. 2004. Genetic diversity among maize (Zea mays L.) landraces assessed by RAPD markers. Genetics and Molecular Biology, 27, 2, 228-236

31. Carvalho, V.P., Ruas, C.F., Ruas, P.M., Ferreira, J.M. and Moreira, R.M.P. 2002. Assessment of genetic diversityin maize (Zea mays L.) landraces using inter simple sequence repeat (ISSR) markers. Crop Breeding and Applied Biotechnology 2:557-568

32. Lanza, L.L.B., De Souza, Jr. C.L., Ottoboni, L.M.M., Vieira, L.M.C. and De Souza, A.P. 1997. Genetic distance of inbred lines and prediction of maize singlecross performance using RAPD markers. Theor. And Appl. Genetic. 94: 1023-1030

33. Heun, M. and Helentjaris, T. 1993. Inheritance of RAPDs in $F_{1}$ hybrids of corn. Theor. App. Genetic 85:961-968

34. Parentoni SN, Magalhães JV, Pacheco CAP, Santos MX, Abadie T, Gama EEG, Guimarães PEO, Meirelles WF, Lopes MA, Vasconcelos MJV and Paiva E. 2001 Heterotic groups based on yield-specific combining ability data and phylogenetic relationship determined by RAPD markers for 28 tropical maize open pollinated varieties. Euphytica 121:197-208

35. Yu, K.F. and Pauls, K.P. 1993. Rapid estimation of genetic relatedness among heterogeneous populations of alfalfa by random amplification of bulked DNA samples. Theor. Appl. Genetics 86 : 788-794

36. Kongkiatngam, P. Waterway, M.J., Coulman, B.E. and Fortin, M.G. 1996. Genetic variation among cultivars of red clover (Trifolium pratence L.) detected by RAPD markers amplified from bulk genomic DNA. Euphytica $89: 355-361$

37. Gimenes M.A. and Lopes C.R. 2000. Isoenzimatic variation in the germplasm of Brazilian races of maize (Zea mays L.). Genetic and Molecular Biology 23:375-380

38. Paterniani E, Nass L.L., Santos MX. 2000. O valor dos recursos genéticos de milho para o Brasil: Uma abordagem histórica da utilização do germoplasma. In: Udry CW and Duarte W (eds) Uma História Brasileira do Milho: O Valor dos Recursos Genéticos. Paralelo 15, Brasília, pp 11-43. 